\title{
Alcohol and ovarian cancer risk: results from the Netherlands Cohort Study
}

Citation for published version (APA):

Schouten, L. J., Zeegers, M. P. A., Goldbohm, R. A., \& van den Brandt, P. A. (2004). Alcohol and ovarian cancer risk: results from the Netherlands Cohort Study. Cancer Causes \& Control, 15(2), 201-209. https://doi.org/10.1023/B:CACO.0000019512.71560.2b

Document status and date:

Published: 01/01/2004

DOI:

10.1023/B:CACO.0000019512.71560.2b

Document Version:

Publisher's PDF, also known as Version of record

\section{Please check the document version of this publication:}

- A submitted manuscript is the version of the article upon submission and before peer-review. There can be important differences between the submitted version and the official published version of record.

People interested in the research are advised to contact the author for the final version of the publication, or visit the DOI to the publisher's website.

- The final author version and the galley proof are versions of the publication after peer review.

- The final published version features the final layout of the paper including the volume, issue and page numbers.

Link to publication

\footnotetext{
General rights rights.

- You may freely distribute the URL identifying the publication in the public portal. please follow below link for the End User Agreement:

www.umlib.nl/taverne-license

Take down policy

If you believe that this document breaches copyright please contact us at:

repository@maastrichtuniversity.nl

providing details and we will investigate your claim.
}

Copyright and moral rights for the publications made accessible in the public portal are retained by the authors and/or other copyright owners and it is a condition of accessing publications that users recognise and abide by the legal requirements associated with these

- Users may download and print one copy of any publication from the public portal for the purpose of private study or research.

- You may not further distribute the material or use it for any profit-making activity or commercial gain

If the publication is distributed under the terms of Article $25 \mathrm{fa}$ of the Dutch Copyright Act, indicated by the "Taverne" license above, 


\title{
Alcohol and ovarian cancer risk: results from the Netherlands Cohort Study
}

\author{
Leo J. Schouten ${ }^{1, *}$, Maurice P.A. Zeegers ${ }^{1}$, R. Alexandra Goldbohm ${ }^{2} \&$ Piet A. van den Brandt ${ }^{1}$ \\ ${ }^{1}$ Department of Epidemiology, NUTRIM, Maastricht University, PO Box 616, 6200 MD Maastricht, \\ The Netherlands; ${ }^{2}$ Department of Nutritional Epidemiology, TNO Nutrition and Food Research Institute, PO Box \\ 360, 3700 AJ Zeist, The Netherlands
}

Received 16 July 2003; accepted in revised form 3 December 2003

Key words: alcohol consumption, cohort studies, ovarian neoplasms etiology, The Netherlands.

\begin{abstract}
Objective: To study alcohol consumption in relation to ovarian cancer risk in a prospective cohort study.

Methods: The Netherlands Cohort Study on diet and cancer was initiated in 1986. A self-administered questionnaire on dietary habits and other risk factors for cancer was completed by 62,573 postmenopausal women. Follow-up for cancer was established by annual record linkages with the Netherlands Cancer Registry. After 9.3 years of followup, 214 incident invasive epithelial ovarian cancer cases and 2211 subcohort members with complete data on alcohol intake were available for analysis. All incidence rate ratios (RRs) were corrected for age, use of oral contraceptives, parity, height, body mass index, energy intake and current cigarette smoking.

Results: The RRs of ovarian cancer for women who consumed up to 5,15 and $>15 \mathrm{~g}$ of alcohol per day were 1.13 (95\% confidence interval, 95\% $\mathrm{CI}=0.79-1.63), 0.85(95 \% \mathrm{CI}=0.53-1.37)$ and $0.92(95 \% \mathrm{CI}=0.55-1.54)$, respectively, compared to non-drinkers. Alcohol consumption in the form of wine, beer or liquor was not associated with ovarian cancer risk.

Conclusion: These data do not suggest a major association between alcohol intake and ovarian cancer risk in this population.
\end{abstract}

\section{Introduction}

In 1988, the International Agency for Research on Cancer concluded that there is sufficient evidence for the carcinogenicity of alcohol in humans [1]. Although experimental studies have not shown a carcinogenic effect of ethanol as such, the epidemiological data with respect to several cancers are strong $[1,2]$.

The effect of alcohol on the risk of ovarian cancer may, however, be different. Alcohol may have an enhancing effect, as it has in other sites, but it could also have a protective effect [3]. In premenopausal women, alcohol intake has been associated with reduced serum levels of gonadotropins [4]. Also, alcohol-fed rats developed

\footnotetext{
* Address correspondence to: Leo J. Schouten, Department of Epidemiology, Nutrition and Toxicology Research Institute Maastricht (NUTRIM), Maastricht University, PO Box 616, 6200 MD Maastricht, The Netherlands. Ph.: +31-43-3882390; Fax: +31-433884128; E-mail: lj.schouten@epid.unimaas.nl
}

significant ovarian atrophy, showing an absence of corpora lutea and developing follicles [5]. Based on these observations, two of the hypotheses for the etiology of ovarian cancer - the 'incessant ovulation' theory of Fathalla [6] and the 'excessive gonadotropin' hypothesis of Cramer and Welch [7] - predict a protective effect of alcohol intake on the risk of ovarian cancer.

The results of published epidemiological studies investigating the association between alcohol consumption and ovarian cancer have been heterogeneous, however. Most case-control studies, often hospitalbased, did not find a statistically significant association [8-16]. Two case-control studies reported statistically significantly decreased risks $[17,18]$, whereas two other case-control studies reported increased risks [19, 20]. To date, only two cohort studies have been conducted. A cohort study with 76 cases among alcoholic women in Sweden [21] showed that the incidence of ovarian cancer was decreased among women under 60 years relative to the general population. Among women of 60 years and 
older, however, there was no association. The second cohort study, with 139 cases, was conducted in Iowa, and found a significantly decreased risk of ovarian cancer [22]. Of the prospective cohort studies, only one adjusted for confounders. We therefore decided to study alcohol consumption in relation to ovarian cancer in a prospective cohort study, allowing adjustment for the main potential confounders.

\section{Materials and methods}

\section{The cohort}

The Netherlands Cohort Study on diet and cancer (NLCS) started in September 1986, when 62,573 Dutch women aged 55-69 years were enrolled in the cohort [23]. All women were presumed to be postmenopausal. Data processing and analysis were based on the casecohort approach, in which the cases were enumerated for the entire cohort (numerator information on incidence rates), while the accumulated person-years of the entire cohort were estimated using a subcohort sample (providing the denominator information). Following this approach, a subcohort of 2589 women was sampled randomly from the cohort after the baseline exposure measurement. The design of the study has been described in detail before [23]. One hundred and fortyfive prevalent cancer cases (other than skin cancer) were excluded from the subcohort. In addition, women in the subcohort who had reported at baseline to have undergone an oophorectomy $(\mathrm{n}=32)$ were excluded, leaving 2412 subcohort members.

\section{Follow-up}

The subcohort has been followed up biennially by mail for vital status information. The vital status of subcohort members who did not respond to the letter was completed by contacting the municipal register. Incident cancer cases occurring in the entire cohort were identified by record linkage to the Netherlands Cancer Registry and the Netherlands National Database for Pathology (PALGA) [23, 24].

The present analysis is restricted to cancer incidence in the 9.3-year follow-up period from September 1986 to December 1995. The completeness of cancer follow-up was estimated to be at least $96 \%$ [25], and no subcohort members were lost to follow-up. During a follow-up period of 9.3 years, 256 incident, microscopically confirmed, primary ovarian malignancies were detected. After exclusion of non-epithelial tumors $(n=15)$ and borderline invasive tumors $(n=6), 235$ cases with epithelial ovarian cancer remained available.

\section{Questionnaire data}

At baseline, cohort members completed a self-administered questionnaire on risk factors for cancer. The food-frequency section concentrated on habitual consumption during the preceding year. Consumption of alcoholic beverages was addressed by questions on beer, red wine, white wine, sherry, other fortified wines, liqueur, and liquor. The questionnaire data of all cases and subcohort members were key-entered twice and processed in a manner blinded with respect to case/ subcohort status in order to minimize observer bias in the coding and interpretation of data. The questionnaire has been validated against a nine-day diet record [26, 27]. The Pearson correlation coefficient between the mean daily ethanol intake assessed by the questionnaire and that estimated by the 9-day record was 0.86 for all subjects and 0.78 for users of alcoholic beverages [26]. Respondents who drank alcoholic beverages less than once a month were considered non-drinkers. Four items from the questionnaire (i.e., red wine, white wine, sherry, and liqueur) were combined into one wine variable, since these items were substantially correlated and separate treatment would have resulted in a sparsity of data. Mean daily alcohol consumption was calculated using the Dutch food composition table [28]. On the basis of pilot study data, standard glass sizes were defined as $200 \mathrm{ml}$ for beer, $105 \mathrm{ml}$ for wine, $80 \mathrm{ml}$ for sherry, and $45 \mathrm{ml}$ for both liqueur and liquor, corresponding to 8 , $10,11,7$, and $13 \mathrm{~g}$ of alcohol, respectively.

\section{Data analysis}

The analysis was based on 214 cases and 2211 subcohort members for whom data on alcohol consumption were complete. Of the 214 epithelial ovarian carcinomas, $35.5 \%$ were serous carcinomas, $10.7 \%$ endometrioid carcinomas, $10.7 \%$ mucinous carcinomas, $4.7 \%$ clear cell carcinomas, $35.5 \%$ adenocarcinomas not otherwise specified and $2.8 \%$ other carcinomas.

The following variables were considered as potential confounders [3, 29, 30]: age (years); use of oral contraceptives (ever versus never); parity (number of children); use of postmenopausal hormones (ever versus never); height $(\mathrm{cm})$; body mass index $\left(\mathrm{kg} / \mathrm{m}^{2}\right)$; family history of breast and/or ovarian cancer (yes versus no); hysterectomy (yes versus no); total energy intake (including energy intake from alcoholic drinks; kcal/day); and current cigarette smoking (yes versus no). Family history was considered positive if breast and/or ovarian cancer was reported in at least one first-degree relative, i.e., mother, sister or daughter. A variable was considered a confounder if (1) the variable was statistically signifi- 
Table 1. Means (standard deviation) and distribution of potential confounders in the subcohort according to alcohol consumption, the Netherlands Cohort Study, 1986-1995

\begin{tabular}{|c|c|c|c|c|c|}
\hline \multirow[t]{2}{*}{ Characteristic } & & \multicolumn{4}{|c|}{ Alcohol consumption } \\
\hline & & $\begin{array}{l}\text { No } \\
(\mathrm{n}=726) \\
\text { Mean }\left(\mathrm{SD}^{\mathrm{a}}\right)\end{array}$ & $\begin{array}{l}0.1-4 \mathrm{~g} / \text { day } \\
(\mathrm{n}=791) \\
\text { Mean }\left(\mathrm{SD}^{\mathrm{a}}\right)\end{array}$ & $\begin{array}{l}5-14 \mathrm{~g} / \text { day } \\
(\mathrm{n}=408) \\
\text { Mean }\left(\mathrm{SD}^{\mathrm{a}}\right)\end{array}$ & $\begin{array}{l}\geq 15 \mathrm{~g} / \text { day } \\
(\mathrm{n}=286) \\
\text { Mean }\left(\mathrm{SD}^{\mathrm{a}}\right)\end{array}$ \\
\hline Age at baseline & Years & $61.7(4.3)$ & $61.4(4.3)$ & $61.5(4.2)$ & $60.8(4.2)$ \\
\hline Parity & no. of children & $3.0(2.4)$ & $2.8(2.3)$ & $2.7(2.0)$ & $2.6(2.0)$ \\
\hline Height & $\mathrm{cm}$ & $164.8(6.7)$ & $165.3(6.1)$ & $165.2(5.9)$ & $166.0(5.8)$ \\
\hline Body mass index & $\mathrm{kg} / \mathrm{m}^{2}$ & $25.5(3.9)$ & $25.2(3.4)$ & $24.5(3.2)$ & $24.4(3.2)$ \\
\hline \multirow[t]{2}{*}{ Energy intake } & kcal & $1617(425)$ & $1674(382)$ & $1724(387)$ & $1793(411)$ \\
\hline & & $\%$ & $\%$ & $\%$ & $\%$ \\
\hline Use of oral contraceptives & Yes & 21.0 & 22.9 & 30.3 & 33.7 \\
\hline Use of postmenopausal hormonal therapy & Yes & 10.8 & 11.8 & 14.8 & 15.4 \\
\hline Hysterectomy & Yes & 5.4 & 5.2 & 9.6 & 8.0 \\
\hline Family history of breast/ovarian cancer ${ }^{b}$ & Yes & 9.6 & 9.5 & 7.1 & 8.0 \\
\hline Currently smoking cigarettes & Yes & 18.9 & 16.6 & 26.0 & 38.1 \\
\hline
\end{tabular}

a $\mathrm{SD}$, standard deviation.

b Family history was considered positive if breast and/or ovarian cancer was reported in at least one first-degree relative, i.e. mother, sister or daughter.

cantly associated with alcohol consumption; (2) the variable is known to be a risk factor for ovarian cancer in this population and (3) the association of alcohol consumption with the risk of ovarian cancer changed by more than $10 \%$ after adjustment for the variable. Cases and subcohort members were excluded from multivariate analyses if information on confounders was missing.

Incidence rate ratios (RR) and corresponding 95\% confidence intervals (CI) for ovarian cancer were estimated in the age-adjusted and multivariate case-cohort analyses with categorized and continuous alcohol variables, using the Cox proportional hazards model [31] processed with the Stata statistical software package [32]. Standard errors were estimated using the robust Hubert-White sandwich estimator to account for additional variance introduced by sampling from the cohort. This method is equivalent to the variance-covariance estimator presented by Barlow [33]. The proportional hazards assumption was tested using the scaled Schoenfeld residuals [34]. Tests for dose-response trends in risk of ovarian cancer were assessed by fitting ordinal exposure variables as continuous terms. Two-sided $p$-values are reported throughout the paper.

\section{Results}

Among subcohort members, women who drank alcohol were slightly younger, had fewer children on average, were taller and leaner and had a higher energy intake than non-drinkers (see Table 1). Of the women who drank alcohol, more had ever used oral contraceptives or postmenopausal hormonal therapy, and more were current cigarette smokers. Because age, use of oral contraceptives, parity, height, body mass index, energy intake and current smoking changed the risk estimates for the association of alcohol consumption with the risk of ovarian cancer, these variables were included as confounders in the multivariate analyses. After exclusion of cases and subcohort members with incomplete information on confounders, 180 cases and 2005 subcohort members were available for multivariate analysis.

The consumption patterns among the women were quite stable. Only $4.7 \%$ of the cohort members and $2.8 \%$ of the cases who consumed less than one alcoholic drink per month at baseline reported to have used alcoholic drinks five years before baseline.

Women who drank $15 \mathrm{~g}$ of alcohol or more per day had a multivariate adjusted relative risk (RR) of 0.92 (95\% CI $=0.55-1.54)$ compared to women who did not drink alcohol (Table 2). The RRs for women who consumed up to 5 or $15 \mathrm{~g}$ per day were not significantly different from 1 either. The $p$-value for trend ( $p$-trend) was non-significant. The multivariate RR for $15 \mathrm{~g}$ or more of alcohol from wine was $1.00(95 \% \mathrm{CI}=0.57-$ 1.75; $p$ trend $=0.95$ ) compared to women who did not drink wine. The multivariate RR for drinking beer was $0.91(95 \% \mathrm{CI}=0.52-1.58)$ and the $\mathrm{RR}$ for drinking liquor was $0.76(95 \% \mathrm{CI}=0.46-1.27)$ compared to nondrinkers of beer and liquor, respectively. In order to evaluate possible bias because of the presence of 


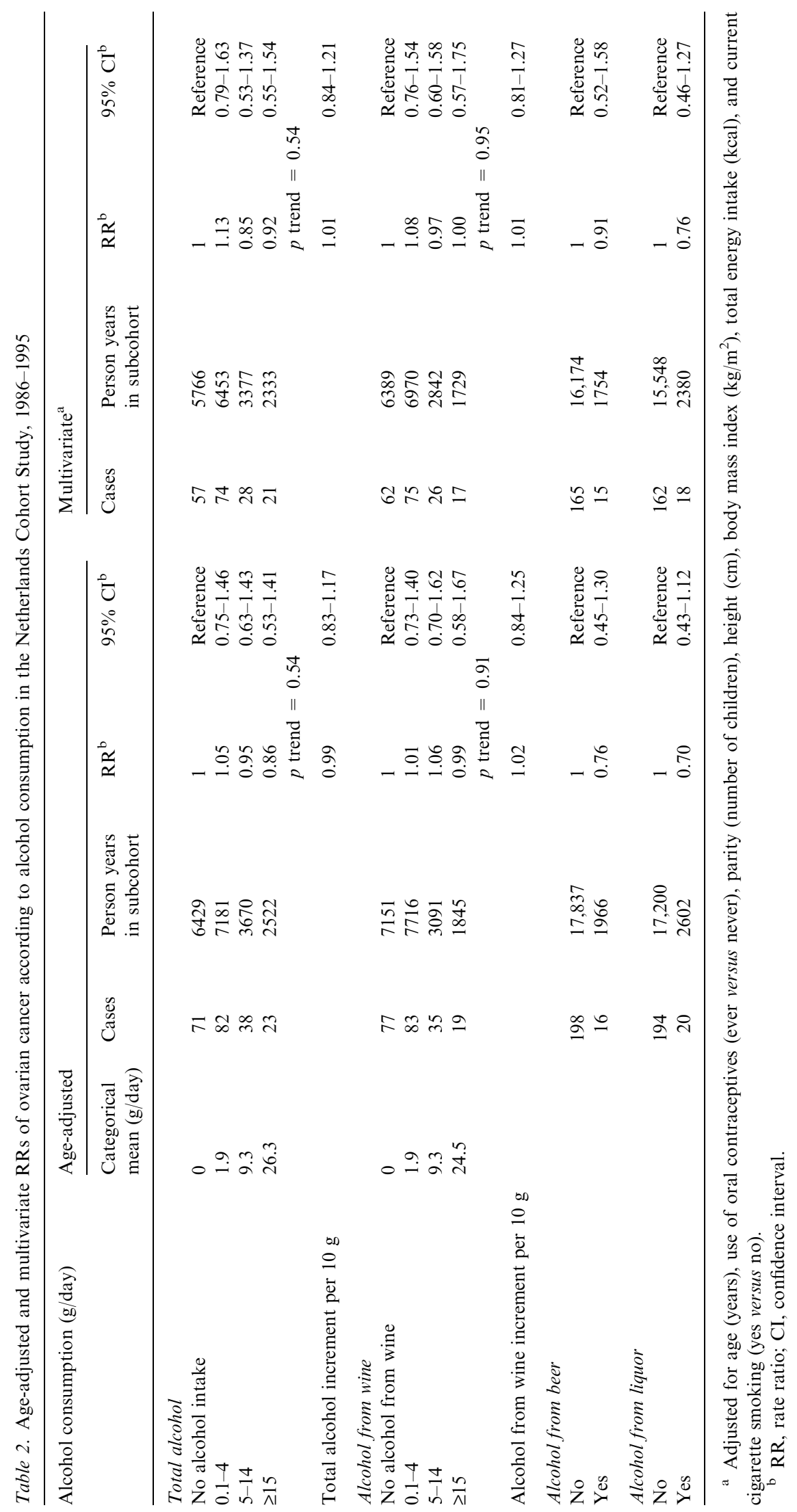


subclinical disease at baseline, the data were analyzed excluding cases and subcohort members with less than one year of follow-up. These risk estimates were not substantially different (data not shown).

We also examined effect modification of the association between alcohol consumption and ovarian cancer by age at baseline, use of oral contraceptives, parity and body mass at baseline (Table 3 ). There was no interaction between age at baseline and alcohol consumption on the one hand and ovarian cancer risk on the other. Among women who had never used oral contraceptives, there was no association with alcohol consumption $(\mathrm{RR}=0.99 ; 95 \% \mathrm{CI}=0.69-1.42)$, while the risk among ever users of oral contraceptives was only slightly and non-significantly increased $(\mathrm{RR}=1.22 ; 95 \% \mathrm{CI}=0.51$ 2.91). The interaction between alcohol consumption and the number of children in terms of the risk of ovarian cancer was not consistent. The interaction with body mass index, however, appeared to show a trend. In women of normal weight (BMI $<25 \mathrm{~kg} / \mathrm{m}^{2}$ ) alcohol consumption was associated with a non-significantly increased relative risk of $1.33(95 \% \mathrm{CI}=0.82$ 2.14). In overweight (BMI $25-<30 \mathrm{~kg} / \mathrm{m}^{2}$ ) and obese $\left(\mathrm{BMI} \geq 30 \mathrm{~kg} / \mathrm{m}^{2}\right.$ ) women, alcohol consumption was associated with non-significantly decreased relative risks of $0.95(95 \% \mathrm{CI}=0.54-1.67)$ and $0.52(95 \% \mathrm{CI}=0.20$ 1.34), respectively. The $p$-value for interaction was 0.21 . There was no interaction between energy intake and alcohol consumption on the one hand and ovarian cancer risk on the other.

\section{Discussion}

This cohort study, with a large number of cases, did not demonstrate a major association between alcohol intake

Table 3. RRs and 95\% CI for ovarian cancer in women who consume alcohol compared to those NOT drinking alcohol among subgroups defined by various risk factors in the Netherlands Cohort Study, 1986-1995

\begin{tabular}{|c|c|c|c|c|}
\hline \multirow[t]{2}{*}{ Subgroup } & \multirow{2}{*}{$\begin{array}{l}\text { Cases } \\
\text { no }\end{array}$} & \multirow{2}{*}{$\begin{array}{l}\text { Subcohort } \\
\text { person years }\end{array}$} & \multicolumn{2}{|c|}{ Drinkers $^{\mathrm{a}}$} \\
\hline & & & $\mathrm{RR}^{\mathrm{b}, \mathrm{c}}$ & $95 \% \mathrm{CI}$ \\
\hline All & 180 & 17,928 & 1.03 & $0.74-1.43$ \\
\hline \multicolumn{5}{|l|}{ Age at baseline (years) } \\
\hline $55-59$ & 62 & 7138 & 1.22 & $0.68-2.17$ \\
\hline $60-64$ & 56 & 5901 & 0.73 & $0.42-1.29$ \\
\hline \multirow[t]{2}{*}{$65-69$} & 62 & 4889 & 1.19 & $0.67-2.11$ \\
\hline & & & $p$ inter & \\
\hline \multicolumn{5}{|c|}{ Use of oral contraceptives } \\
\hline Never & 150 & 13,287 & 0.99 & $0.69-1.42$ \\
\hline Ever & 30 & 4640 & 1.22 & $0.51-2.91$ \\
\hline \multicolumn{5}{|c|}{ Parity (number of children) } \\
\hline No & 50 & 3115 & 1.01 & $0.52-1.96$ \\
\hline 1 & 14 & 1527 & 0.50 & $0.16-1.49$ \\
\hline 2 & 38 & 3980 & 1.98 & $0.89-4.41$ \\
\hline \multirow[t]{2}{*}{$3+$} & 78 & 9307 & 0.90 & $0.56-1.46$ \\
\hline & & & $p$ inter & \\
\hline \multicolumn{5}{|c|}{ Body mass at baseline $\left(\mathrm{kg} / \mathrm{m}^{2}\right)$} \\
\hline Normal $(<25)$ & 98 & 10,098 & 1.33 & $0.82-2.14$ \\
\hline Overweight $(25-<30)$ & 61 & 6286 & 0.95 & $0.54-1.67$ \\
\hline \multirow[t]{2}{*}{ Obese $(30+)$} & 21 & 1544 & 0.52 & $0.20-1.34$ \\
\hline & & & $p$ inter & \\
\hline \multicolumn{5}{|l|}{ Energy intake (kcal/day) } \\
\hline$<1745$ & 35 & 3527 & 1.07 & $0.53-2.17$ \\
\hline $1745-<1998$ & 38 & 3562 & 1.86 & $0.83-4.19$ \\
\hline $1998-<2250$ & 31 & 3563 & 0.51 & $0.24-1.05$ \\
\hline $2250-<2563$ & 41 & 3547 & 0.94 & $0.46-1.92$ \\
\hline \multirow[t]{2}{*}{$\geq 2563$} & 35 & 3729 & 1.02 & $0.46-2.25$ \\
\hline & & & $p$ inter & \\
\hline
\end{tabular}

\footnotetext{
a Compared to non-drinkers (=reference category).

b $\mathrm{RR}=$ rate ratio; $95 \% \mathrm{CI}=95 \%$ Confidence Interval.

c Adjusted for age (years), use of oral contraceptives (ever versus never), parity (number of children), height (cm), body mass index (kg/m ${ }^{2}$ ), total energy intake (kcal), and current cigarette smoking (yes versus no).
} 
and ovarian cancer incidence after controlling for several potential confounders among postmenopausal women. RRs for women who drank alcohol were slightly decreased compared to those for non-drinkers, but the difference was not statistically significant.

An important strength of our study is the prospective design, which makes recall bias unlikely. Bias resulting from the presence of subclinical disease at baseline is also unlikely, because an analysis excluding all cases and subcohort members with less than one year of follow-up did not change the results significantly. RRs were not significantly different. Selection bias is unlikely, given the high degree of completeness of the follow-up in terms of cases and subcohort person years [25, 35]. Another advantage is that the assessment of alcohol consumption in the NLCS allowed us to evaluate a possible association between different types of alcoholic beverage and ovarian cancer risk.

A possible limitation of our study is misclassification of alcohol consumption. The correlation between the alcohol consumption measured by the questionnaire and the measurement in a nine-day record was high, due to the large variation in alcohol consumption [26]. Also, if misclassification has occurred, this is expected to be non-differential and risk estimates are most likely biased toward no effect. Abstainers and ex-drinkers were not separated in our study, but were included in our reference category of non-drinkers. Since ex-drinkers may differ from abstainers in ovarian cancer risk, our estimated risks might be biased in either direction. The proportion of ex-drinkers is probably small, as only $4.7 \%$ of the cohort members and $2.8 \%$ of the cases who consumed less than one alcoholic drink per month reported to have drunk alcohol five years before baseline. We were able to control for confounding by the most important risk factors of ovarian cancer [29].

Of the hospital-based case-control studies that have investigated the association between alcohol and the risk of ovarian cancer (for an overview of all epidemiological studies see Table 4), two studies did not find an effect [8, 9] and five studies reported an increased risk [10-12, 19, 20]. Two of these studies observed a statistically significant trend with increasing alcohol consumption $[19,20]$. One other study [18] found a protective effect of alcohol consumption, which became statistically nonsignificant in multivariate analysis. One other study did not find an overall effect [13], but found a protective effect of alcohol consumption in women under 50 years of age, though the effect was not statistically significant. It must be remembered, however, that hospital-based case-control studies on alcohol consumption may suffer from selection and information bias, because alcohol is linked to many diseases that require hospitalization.
Three population-based case-control studies have published results on alcohol and ovarian cancer [14, $15,17]$, of which two found non-significant protective effects of alcohol consumption [14, 17] and the third a non-significantly increased risk [15]. Two cohort studies have studied the issue. In Sweden [21], the incidence of ovarian cancer at the age of 60 years and older was unaltered in alcoholic women, but the incidence under the age of 60 was $24 \%$ lower than expected in alcoholic women compared to the general population. The study design did not allow adjustment for confounding. In the Iowa Women's Health Study, a decreasing risk of ovarian cancer was observed with increasing alcohol consumption [22]. In the highest category, the RR was 0.49 after adjustment for several confounders.

Differences in the level of alcohol consumption do not explain the heterogeneity of the outcomes. The Iowa Women's Health Study [22] observed a statistically significantly decreased risk of ovarian cancer, but alcohol consumption even in the highest category was rather low (about one glass/day). The Swedish cohort study [21] was conducted among alcoholics, with a high consumption of alcohol. These women, however, probably differed in many respects from the general population, making it difficult to interpret these results. Some of the studies that observed an increased risk, although not always statistically significant, involved persons with a relatively high consumption of alcohol: more than two $[11,12]$ or more than three glasses per day $[15,20]$. The alcohol consumption in the current study was relatively low: the highest category consisted of women who drank an average of 1.5 or more glasses of alcoholic beverage per day.

It is conceivable that both carcinogenic and protective effects of alcohol play a role in ovarian cancer. Carcinogenic effects may include an altered carcinogen metabolism [2] or alcohol-related nutritional deficiencies, e.g., a lack of folate [36]. The main etiological hypotheses of ovarian cancer, i.e., the 'incessant ovulation' theory of Fathalla [6] and the 'excessive gonadotropins' hypothesis of Cramer and Welch [7], indicate that suppression of ovulation and leveling of the peaks in gonadotropin levels may protect against ovarian cancer. This potential protective effect of alcohol is probably largest in the fertile period, which is in agreement with studies showing decreased risk ratios especially in younger women $[13,17,21]$, but not with other studies showing increased risks in younger women $[9,20]$. The current study showed a slightly increased risk in the youngest age group. It must be remembered, however, that the women were already 55-69 years of age at baseline, and the power to detect a protective effect - if any - in the youngest women of our cohort was probably too small. Based on Fathalla's 
Table 4. Summary of epidemiological study findings on the relation between alcohol intake and ovarian cancer risk

\begin{tabular}{|c|c|c|c|c|c|}
\hline Reference & Study population & Age (years) & Level of alcohol consumption & $\mathrm{RR} / \mathrm{OR}(95 \% \mathrm{CI})^{\mathrm{a}}$ & $p$ trend \\
\hline \multicolumn{6}{|c|}{ Hospital-based case-control studies } \\
\hline \multirow[t]{3}{*}{ Williams \& Horm [10] } & 153 cases & All & Non-drinkers & 1 (reference) & - \\
\hline & 3035 controls & & $1-50$ oz-years & $0.74(\mathrm{NS})$ & \\
\hline & & & 51 or more oz-years & $0.85(\mathrm{NS})$ & \\
\hline \multirow{3}{*}{ Byers et al. [13] } & 274 cases & $30-79$ & Non-drinkers & 1 (reference) & NS \\
\hline & 1034 controls & & 1-8 drinks/week & $0.92(\mathrm{NS})$ & \\
\hline & & & $\geq 9$ drinks/week & $0.83(\mathrm{NS})$ & \\
\hline \multirow[t]{7}{*}{ Tzonou et al. [19] } & 150 cases & All & Non-drinkers & 1 (reference) & \\
\hline & 250 controls & & Drinkers & $1.5(0.9-2.5)$ & \\
\hline & & & Years of consumption: & & \\
\hline & & & $1-9$ & $0.7(0.2-2.2)$ & 0.02 \\
\hline & & & $10-19$ & $1.9(0.7-4.8)$ & \\
\hline & & & $20-29$ & $2.9(1.1-7.6)$ & \\
\hline & & & $30+$ & $1.7(0.8-3.5)$ & \\
\hline \multirow[t]{2}{*}{ Mori et al. [8] } & 110 cases & All & <once/week & 1 (reference) & - \\
\hline & 220 controls & & zonce/week & $1.0(0.6-1.9)$ & \\
\hline \multirow[t]{5}{*}{ Hartge et al. [11] } & 296 cases & $20-79$ & Non-drinkers & 1 (reference) & 0.14 \\
\hline & 343 controls & & Occasional & $1.1(0.7-1.9)$ & \\
\hline & & & 1-6 drinks/week & $1.4(0.8-2.3)$ & \\
\hline & & & 7-13 drinks/week & $1.2(0.7-2.2)$ & \\
\hline & & & $\geq 14$ drinks/week & $1.5(0.8-2.8)$ & \\
\hline \multirow[t]{3}{*}{ Kato et al. [18] } & 417 cases & $20+$ & None & 1 (reference) & - \\
\hline & 8920 controls & & Occasional & $1.10(0.79-1.53)$ & \\
\hline & & & Daily & $0.38(0.16-0.90)$ & \\
\hline \multirow[t]{5}{*}{ La Vecchia et al. [20] } & 801 cases & $<75$ & None & 1 (reference) & 0.04 \\
\hline & 2114 controls & & $<1$ drink/day & $1.0(0.7-1.4)$ & \\
\hline & & & $1-<2$ drinks/day & $1.1(0.9-1.4)$ & \\
\hline & & & $2-<3$ drinks/day & $1.2(1.0-1.5)$ & \\
\hline & & & $\geq 3$ drinks/day & $1.3(0.9-1.8)$ & \\
\hline \multirow[t]{4}{*}{ Polychronopoulou et al. [12] } & 189 cases & $<75$ & None & 1 (reference) & - \\
\hline & 200 controls & & $\leq 1$ glass/day & $0.85(0.52-1.39)$ & \\
\hline & & & $1-\leq 2$ glasses/day & $0.94(0.49-1.79)$ & \\
\hline & & & $>2$ glasses/day & $1.62(0.66-3.96)$ & \\
\hline \multirow[t]{3}{*}{ Nandakumar et al. [16] } & 97 cases & $48.3^{\mathrm{c}}$ & History of alcohol consumption: & & - \\
\hline & 194 controls & & No & 1 (reference) & \\
\hline & & & Yes & $1.3(0.2-8.0)$ & \\
\hline \multirow[t]{5}{*}{ Tavani et al. [9] } & 1031 cases & $<80$ & Never drinkers & 1 (reference) & 0.41 \\
\hline & 2411 controls & & $<12$ g/day & $1.02(0.80-1.30)$ & \\
\hline & & & $>12-24 \mathrm{~g} /$ day & $1.29(1.00-1.67)$ & \\
\hline & & & $>24-36 \mathrm{~g} /$ day & $1.04(0.80-1.36)$ & \\
\hline & & & $\geq 36 \mathrm{~g} /$ day & $1.09(0.76-1.57)$ & \\
\hline \multicolumn{6}{|c|}{ Population-based case-control studies } \\
\hline \multirow[t]{5}{*}{ Gwinn et al. [17] } & 433 cases & $20-54$ & None & 1 (reference) & - \\
\hline & 2915 controls & & $<50 \mathrm{~g} /$ week & $1.0(0.7-1.4)$ & \\
\hline & & & $50-149 \mathrm{~g} /$ week & $0.8(0.5-1.1)$ & \\
\hline & & & $150-249 \mathrm{~g} /$ week & $1.0(0.6-1.6)$ & \\
\hline & & & $\geq 250 \mathrm{~g} /$ week & $0.5(0.2-0.9)$ & \\
\hline \multirow[t]{2}{*}{ Whittemore et al. [14] } & 188 cases & $18-74$ & None & 1 (reference) & - \\
\hline & 539 controls & & $\geq 20$ drinks/week & $0.66(p=0.34)$ & \\
\hline \multirow[t]{5}{*}{ Kuper et al. [15] } & 549 cases & & None & 1 (reference) & 0.20 \\
\hline & 516 controls & & 0-1 drinks/day & $0.91(0.67-1.23)$ & \\
\hline & & & $>1-2$ drinks/day & $1.33(0.88-2.01)$ & \\
\hline & & & $>2-3$ drinks/day & $0.92(0.50-1.69)$ & \\
\hline & & & $>3$ drinks/day & $1.35(0.80-2.26)$ & \\
\hline \multicolumn{6}{|l|}{ Cohort studies } \\
\hline \multirow[t]{2}{*}{ Kushi et al. [22] } & 29,083 subjects & $55-69^{b}$ & None & 1 (reference) & 0.01 \\
\hline & 139 cases & & $0.9-3.9 \mathrm{~g} /$ day & $1.37(0.39-2.04)$ & \\
\hline
\end{tabular}


Table 4. (Continued)

\begin{tabular}{|c|c|c|c|c|c|}
\hline Reference & Study population & Age (years) & Level of alcohol consumption & $\mathrm{RR} / \mathrm{OR}(95 \% \mathrm{CI})^{\mathrm{a}}$ & $p$ trend \\
\hline & & & $4-<10 \mathrm{~g} /$ day & $0.61(0.28-1.34)$ & \\
\hline & & & $\geq 10 \mathrm{~g} /$ day & $0.49(0.24-1.01)$ & \\
\hline \multirow[t]{2}{*}{ Lagiou et al. [21] } & 36,856 subjects & $42.7^{\mathrm{b}, \mathrm{c}}$ & General population & 1 (reference) & - \\
\hline & 76 cases & & Alcoholics & $0.86(0.68-1.08)$ & \\
\hline \multirow[t]{4}{*}{ Schouten et al. (current study) } & 214 cases & $55-69^{b}$ & None & 1 (reference) & 0.54 \\
\hline & & & $<5$ g/day & $1.13(0.79-1.63)$ & \\
\hline & & & $5-14 \mathrm{~g} /$ day & $0.85(0.53-1.37)$ & \\
\hline & & & $\geq 15 \mathrm{~g} /$ day & $0.92(0.55-1.54)$ & \\
\hline
\end{tabular}

${ }^{\text {a }} \mathrm{RR}=$ Risk ratio; OR $=$ Odds ratio; 95\% CI $=95 \%$ Confidence intervals; reference $=$ reference category; NS $=$ non-significant.

b Age at enrollment.

c Mean age.

theory, one might also expect that, because of the similarity of the proposed mechanisms of protection, alcohol would not provide additional protection against ovarian cancer in women who used oral contraceptives, as ovulation is already suppressed in these women. In the current study, women who used oral contraceptives and consumed alcohol had a slightly but not statistically significantly increased risk of ovarian cancer compared to women who did not consume alcohol. Two other case-control studies have studied the interaction between the use of oral contraceptives and alcohol intake. Both studies observed a nonsignificant protective effect of alcohol intake in women who had ever used oral contraceptives [9, 20].

An interesting finding in the current study was the decreased - although not statistically significantly decreased - risk of ovarian cancer in overweight and obese women who consumed alcohol. This was not confirmed in the only case-control study that investigated this interaction [9]. In view of the possibility of a chance finding, confirmation of this result in other studies is needed. Tavani [9] observed a protective effect of alcohol intake among women with a low energy intake. This was not confirmed in the current study.

In conclusion, alcohol intake was not associated with ovarian cancer risk in our cohort study. We cannot exclude that alcohol intake protects against ovarian cancer occurring at younger age, because the women in our cohort were already too old at baseline to demonstrate or refute this effect. Future studies on alcohol intake should focus on younger cohorts and should investigate a possible interaction with oral contraceptives and body mass index.

\section{Acknowledgements}

The authors would like to thank the Netherlands Cancer Registry (IKA, IKL, IKMN, IKN, IKO, IKR, IKST,
IKW, and IKZ) and the Netherlands National Database for Pathology, PALGA for providing incidence data; Jan Klerkx for linguistic comments, Dr Arnold Kester for statistical advice; Sacha van de Crommert, Jolanda Nelissen, Henny Brants, Conny de Zwart, Marijke Moll, Eric Busink and Linda van den Bosch, for assistance; and Harry van Montfort, Ruud Schmeitz, T. van Montfort and Ton van Moergastel for programming.

\section{References}

1. Alcohol drinking (1988) IARC Working Group, Lyon, 13-20 October 1987. IARC Monogr Eval Carcinog Risks Hum 44: 1378 .

2. World Cancer Research Fund, American Institute for Cancer Research (1997) Food, Nutrition and the Prevention of Cancer: a Global Perspective. Washington DC: World Cancer Research Fund/ American Institute for Cancer Research, pp. 1-670.

3. Gertig D, Hunter D (2002) Ovarian Cancer. In: Adami H-O, Hunter D, Trichopoulos D, eds. Textbook of Cancer Epidemiology, Oxford: Oxford University Press, pp. 378-399.

4. Verkasalo PK, Thomas HV, Appleby PN, Davey GK, Key TJ (2001) Circulating levels of sex hormones and their relation to risk factors for breast cancer: a cross-sectional study in 1092 pre- and postmenopausal women (United Kingdom). Cancer Causes Control 12: 47-59.

5. Van Thiel DH, Gavaler JS, Lester R (1977) Ethanol: a gonadal toxin in the female. Drug Alcoh Depend 2: 373-380.

6. Fathalla MF (1971) Incessant ovulation - a factor in ovarian neoplasia? Lancet 2: 163 .

7. Cramer DW, Welch WR (1983) Determinants of ovarian cancer risk. II. Inferences regarding pathogenesis. J Natl Cancer Inst 71: 717-721.

8. Mori M, Harabuchi I, Miyake H, et al. (1988) Reproductive, genetic, and dietary risk factors for ovarian cancer. Am J Epidemiol 128: $771-777$.

9. Tavani A, Gallus S, Dal Maso L, et al. (2001) Coffee and alcohol intake and risk of ovarian cancer: an Italian case-control study. Nutr Cancer 39: 29-34.

10. Williams RR, Horm JW (1977) Association of cancer sites with tobacco and alcohol consumption and socioeconomic status of patients: interview study from the Third National Cancer Survey. J Natl Cancer Inst 58: 525-547. 
11. Hartge P, Schiffman MH, Hoover R, et al. (1989) A case-control study of epithelial ovarian cancer. Am J Obstet Gynecol 161: 10-16.

12. Polychronopoulou A, Tzonou A, Hsieh CC, et al. (1993) Reproductive variables, tobacco, ethanol, coffee and somatometry as risk factors for ovarian cancer. Int $J$ Cancer 55: 402-407.

13. Byers T, Marshall J, Graham S, Mettlin C, Swanson M (1983) A case-control study of dietary and nondietary factors in ovarian cancer. J Natl Cancer Inst 71: 681-686.

14. Whittemore AS, Wu ML, Paffenbarger RS, Jr, et al. (1988) Personal and environmental characteristics related to epithelial ovarian cancer. II. Exposures to talcum powder, tobacco, alcohol, and coffee. Am J Epidemiol 128: 1228-1240.

15. Kuper H, Titus Ernstoff L, Harlow BL, Cramer DW (2000) Population based study of coffee, alcohol and tobacco use and risk of ovarian cancer. Int $J$ Cancer 88: 313-318.

16. Nandakumar A, Anantha N, Dhar M, et al. (1995) A case-control investigation on cancer of the ovary in Bangalore, India. Int $J$ Cancer 63: 361-365.

17. Gwinn ML, Webster LA, Lee NC, Layde PM, Rubin GL (1986) Alcohol consumption and ovarian cancer risk. Am J Epidemiol 123: 759-766.

18. Kato I, Tominaga S, Terao C (1989) Alcohol consumption and cancers of hormone-related organs in females. Jpn J Clin Oncol 19 202-207.

19. Tzonou A, Day NE, Trichopoulos D, et al. (1984) The epidemiology of ovarian cancer in Greece: a case-control study. Eur $J$ Cancer Clin Oncol 20: 1045-1052.

20. La Vecchia C, Negri E, Franceschi S, et al. (1992) Alcohol and epithelial ovarian cancer. J Clin Epidemiol 45: 1025-1030.

21. Lagiou $\mathrm{P}, \mathrm{Ye} \mathrm{W}, \mathrm{Wedren} \mathrm{S}$, et al. (2001) Incidence of ovarian cancer among alcoholic women: a cohort study in Sweden. Int $J$ Cancer 91: 264-266.

22. Kushi LH, Mink PJ, Folsom AR, et al. (1999) Prospective study of diet and ovarian cancer. Am J Epidemiol 149: 21-31.

23. van den Brandt PA, Goldbohm RA, van't Veer P, et al. (1990) A large-scale prospective cohort study on diet and cancer in The Netherlands. J Clin Epidemiol 43: 285-295.

24. van den Brandt PA, Schouten LJ, Goldbohm RA, Dorant E, Hunen PM (1990) Development of a record linkage protocol for use in the Dutch Cancer Registry for Epidemiological Research. Int $J$ Epidemiol 19: 553-558.

25. Goldbohm RA, van den Brandt PA, Dorant E (1994) Estimation of the coverage of Dutch municipalities by cancer registries and PALGA based on hospital discharge data. Tijdschr Soc Gezondheidsz 72: 80-84.

26. Goldbohm RA, van den Brandt PA, Brants HA, et al. (1994) Validation of a dietary questionnaire used in a large-scale prospective cohort study on diet and cancer. Eur J Clin Nutr 48: 253-265.

27. Goldbohm RA, van't Veer P, van den Brandt PA, et al. (1995) Reproducibility of a food frequency questionnaire and stability of dietary habits determined from five annually repeated measurements. Eur J Clin Nutr 49: 420-429.

28. Stichting NEVO (1986) NEVO-tabel; Nederlands Voedingsstoffenbestand 1986-1987. The Hague: Voorlichtingsbureau voor de Voeding.

29. Weiss NS, Cook LS, Farrow DC, Rosenblatt KA (1996) Ovarian cancer. In: Schottenfeld D, Fraumeni JF, eds. Cancer Epidemiology and Prevention. New York: Oxford University Press, pp. 10401057.

30. Schouten LJ, Goldbohm RA, van den Brandt PA (2003) Height, weight, weight change, and ovarian cancer risk in the Netherlands cohort study on diet and cancer. Am J Epidemiol 157: 424-433.

31. Cox Dr (1972) Regression models and life-tables (with discussion). $J$ R Stat Soc Ser B. 34: 187-220.

32. Cleves MA, Gould WW, Gutierrez RG (2002) An Introduction to Survival Analysis Using Stata. Texas: Stata Press, pp. 1-290.

33. Barlow WE (1994) Robust variance estimation for the case-cohort design. Biometrics 50: 1064-1072.

34. Schoenfeld D (1982) Partial residuals for the proportional hazards regression model. Biometrika 69: 239-241.

35. van den Brandt PA, van't Veer P, Goldbohm RA, et al. (1993) A prospective cohort study on dietary fat and the risk of postmenopausal breast cancer. Cancer Res 53: 75-82.

36. Konings EJ, Goldbohm RA, Brants HA, Saris WH, van den Brandt PA (2002) Intake of dietary folate vitamers and risk of colorectal carcinoma: results from The Netherlands Cohort Study. Cancer 95: 1421-1433. 